\title{
KAJIAN STRATEGI PENGEMBANGAN INDUSTRI PENGOLAHAN IKAN DI KOTA PALOPO PROVINSI SULAWESI SELATAN
}

\section{(THE DEVELOPMENT STRATEGY STUDY OF FISH PROCESSING INDUSTRY IN PALOPO CITY SOUTH SULAWESI PROVINCE)}

\author{
Ummi Maksum Marwan ${ }^{1,2}$, Budy Wiryawan², Ernani Lubis ${ }^{2}$ \\ ${ }^{1}$ Corresponding author \\ ${ }^{2}$ Departemen Pemanfaatan Sumberdaya Perikanan, \\ Fakultas Perikanan dan Ilmu Kelautan, Institut Pertanian Bogor \\ E-mail: ummimaksum@yahoo.com
}

\begin{abstract}
The fishing industry is one of industry that has the potential to be developed. Specifically Indonesian fisheries potential quite large and can be an opportunity to build fish processing industry. Palopo town has a structure that embodies the policy center that strengthen agro industry activities, trade and services as well as tourism and other municipal activities optimally. In addition, the fisheries subsector is featured subsector in Palopo. Therefore, the study of fish processing industry development in Palopo done, it aims to determine the appropriate strategy for Palopo conditions. The analytical method used are qualitative descriptive and SWOT. Results by using SWOT analysis concluded that the strategies that can be offered were 1) strengthening and developing an integrated fish processing group from local coastal community; 2) utilizing and maintaining the cold storage, ice factory, and fish processing building; 3) expanding the market especially processed fish products; and 4) easy administration access for local fish industry.
\end{abstract}

Keywords: Development, fish processing industry, Palopo

\begin{abstract}
ABSTRAK
Industri perikanan tangkap merupakan salah satu industri yang berpotensi untuk dikembangkan. Potensi perikanan tangkap Indonesia tergolong besar dan dapat dijadikan peluang dalam membangun industri pengolahan ikan. Kota Palopo memiliki kebijakan struktur ruang yang mewujudkan pusat kegiatan yang memperkuat kegiatan agroindustri, perdagangan dan jasa serta pariwisata dan kegiatan kota lainnya secara optimal. Subsektor perikanan merupakan subsektor unggulan di Kota Palopo. Kajian tentang pengembangan industri pengolahan ikan di Kota Palopo dilakukan, bertujuan untuk menentukan strategi yang sesuai untuk kondisi Kota Palopo. Metode analisis yang digunakan adalah deskriptif kualitatif dan SWOT. Hasil analisis menggunakan SWOT menyimpulkan bahwa strategi yang dapat diterapkan dalam rangka mendorong pengembangan industri pengolahan ikan di Kota Palopo diantaranya: (1) penguatan dan pengembangan kelompok pengolah ikan terpadu masyarakat pesisir; (2) memanfaatkan dan memelihara fasilitas penanganan hasil tangkapan yang tersedia yaitu chilling room, pabrik es, dan gedung pengolahan ikan; (3) mengembangkan jangkauan pasar terutama produk olahan hasil perikanan; (4) mempermudah akses administrasi pendirian industri pengolahan ikan di daerah; dan (5) meningkatkan daya saing volume produksi hasil tangkapan ikan nelayan lokal Kota Palopo di PPI Pontap.
\end{abstract}

Kata kunci: Pengembangan, industri pengolahan ikan, Palopo

\section{PENDAHULUAN}

Menurut Mulyadi (2005), Indonesia lebih terkonsentrasi pada industri manufaktur dan jasa yang banyak menggunakan bahan baku dari luar negeri. Industri yang berbasis sumber daya alam (resources based industries), yaitu industri perikanan yang merupakan salah satu komponen dari industri promosi ekspor, tidak mendapat tempat dan prioritas sewajarnya. Kebangkrutan industri manufaktur dan jasa akibat krisis ekonomi dan moneter mengharuskan kita untuk melakukan usaha-usaha penciptaan sumber pertumbuhan ekonomi baru yang berbasis sumber daya alam.

Industri perikanan tangkap merupakan salah satu industri yang berpotensi untuk dikembangkan. Potensi perikanan tangkap Indonesia secara spesifik tergolong besar dan sangat beragam. Arah pengelolaan perikanan saat ini ada kecenderungan ke arah peningkatan produksi tanpa memperhatikan aspek nilai tambahnya, sehingga terjadi eksploitasi 
sumber daya ikan secara berlebihan. Eksploitasi besar-besaran tersebut umumnya tidak diikuti dengan peningkatan pendapatan dan kesejahteraan yang signifikan pada masyarakat pesisir. Sebagai contoh, kasus pembuangan ikan yang terjadi di Ternate, Maluku Utara sebagai akibat dari tidak adanya kesiapan pasar untuk menerima hasil tangkapan (Kompas, 2012). Kasus berton-ton ikan yang busuk akibat kurangnya penanganan ikan di tempat pendaratan (kurang pasokan es dan tidak terdapat cold storage) yang terjadi di Aceh Selatan (Harian Analisa, 2012). Sifat ikan mudah rusak (highly perishable) sehingga ikan yang tidak terjual secara segar perlu penanganan yang lebih lanjut (diolah) untuk menjaga stabilitas harga ikan ketika mencapai musim puncak. Pengolahan dalam hal ini memiliki peranan yang penting untuk mempertahankan mutu produk hasil perikanan.

Potensi perikanan tangkap Sulawesi Selatan sebesar 620.480 ton/tahun, dengan rincian; Selat Makassar dengan potensi 307.380 ton/tahun, Laut Flores dengan potensi 168.780 ton/tahun, dan Teluk Bone dengan potensi sebesar 144.320 ton/tahun (Hatta, 2007). Salah satu tempat pendaratan ikan di Sulawesi Selatan yang paling sering disinggahi adalah PPI Pontap di Kota Palopo. Hal ini dikarenakan fasilitas yang disediakan di PPI tersebut lebih lengkap dan lebih baik dari PPI lainnya (Suardi, 2005).

Perbedaan karakteristik sumber daya ikan, sumber daya manusia, sumber daya teknologi di setiap daerah mengakibatkan potensi pengembangan industri perikanan juga berbeda-beda. Penting untuk mengidentifikasi potensi suatu wilayah dalam upaya pengembangan industri. Dengan mengetahui potensi yang dimiliki, maka dapat dibuat strategi yang tepat guna mendorong pengembangan industri yang sesuai. Strategi adalah cara penyusunan tindakan-tindakan yang dilakukan oleh pengelola perusahaan untuk mencapai misi, sasaran dan tujuan perusahaan (Najib dan Hubeis, 2008). Perencanaan strategi akan membantu stakeholder utamanya pemerintah daerah dalam mengambil keputusan yang tepat. Untuk mewujudkan hal tersebut, maka perlu dilakukan kajian strategi pengembangan industri pengolahan ikan di Kota Palopo Provinsi Sulawesi Selatan. Penelitian ini bertujuan untuk menen- tukan strategi pengembangan industri pengolahan ikan di Kota Palopo.

\section{METODOLOGI}

\subsection{Tempat dan Waktu}

Penelitian dilaksanakan pada bulan Januari hingga bulan Maret Tahun 2013 bertempat di Kota Palopo dan Kabupaten Luwu Raya, Provinsi Sulawesi Selatan.

\subsection{Metode Penelitian}

Penelitian ini menggunakan metode studi kasus yang mengkaji tentang strategi pengembangan industri pengolahan ikan di Kota Palopo.

\subsection{Metode Pengumpulan Data}

Data yang dikumpulkan berupa data primer dan data sekunder. Data primer diperoleh melalui pengamatan langsung di lapangan dan wawancara menggunakan kuesioner. Metode pengambilan contoh yang digunakan adalah purposive sampling. Responden yang dijadikan sampel terdiri dari 2 orang pegawai pemerintah daerah Kota Palopo, 3 orang pegawai dinas kelautan dan perikanan Kota Palopo, 1 orang pengolah ikan yang merupakan ketua kelompok pengolah ikan, 10 orang nelayan dan 10 orang pedagang ikan di Pangkalan Pendaratan Ikan Pontap yang dianggap berpengaruh dan mengetahui keadaan perikanan di lokasi penelitian. Data sekunder diperoleh melalui instansi terkait dan studi literatur.

\subsection{Metode Analisis}

Perumusan strategi dilakukan menggunakan analisis SWOT. Kebijakan strategis yang efektif dapat dirumuskan secara sistematis dengan membandingkan kondisi internal dan eksternal lingkungan. Analisis lingkungan internal berkaitan dengan kekuatan dan kelemahan. Analisis eksternal berkaitan dengan peluang dan ancaman. Analisis ini didasarkan pada logika dapat memaksimalkan kekuatan (Strength) dan peluang (opportunities), namun secara bersamaan dapat meminimalkan kelemahan (weaknesses) dan ancaman (threats) (Rangkuti, 2000). Dalam pembuatan analisis SWOT agar keputusan yang diperoleh lebih tepat, maka perlu melalui tahapan-tahapan proses sebagai berikut 
(Marimin 2004 diacu dalam Nazdan et al, 2008):

1. Tahap evaluasi faktor lingkungan eksternal dan internal. Tahap ini digunakan untuk mengidentifikasi faktor-faktor yang menjadi kekuatan, kelemahan, peluang dan ancaman dengan menganalisis data yang relevan dengan lingkup penelitian,

2. Tahap analisis (analisis SWOT), yaitu pembuatan matrik internal dan matriks eksternal serta matriks SWOT. Setiap faktor internal dan eksternal ditentukan bobotnya. Bobot (B) setiap faktor memiliki nilai antara 0 (tidak penting) sampai 1 (sangat penting). Bobot ini menyatakan seberapa penting setiap faktor tersebut, dengan total seluruh bobot sama dengan 1 . Bobot tersebut ditentukan dengan membandingkan derajat kepentingan setiap faktor yang satu dengan faktor yang lain dengan mengunakan pendekatan matrik banding berpasangan. Faktor-faktor tersebut kemudian diberi rating $(\mathrm{R})$ yang menandakan nilai dukungan masing-masing faktor dalam pencapaian tujuan. Penilaian menggunakan skala Likert yang dimulai dari rating 4 (sangat berpengaruh), 3 (berpengaruh), 2 ( kurang berpengaruh) dan 1 (tidak ber-pengaruh). Bobot faktor dan rating akan menentukan skor $(\mathrm{BxR})$ atau nilai bobot dukungan terhadap pengembangan industri pengolahan ikan di Kota Palopo. Dalam tahap ini peneliti membuat justifikasi sendiri terhadap nilai tingkat kepentingan dan rating dari setiap faktor berdasarkan data dan kondisi aktual di lapangan yang berpengaruh terhadap pencapaian strategi pengembangan industri pengolahan ikan. Selanjutnya dari jumlah skor dalam setiap faktor SWOT diperoleh total skor faktor internal dan skor faktor eksternal yang digunakan untuk mengetahui posisi strategi pengembangan industri pengolahan ikan di Kota Palopo pada posisi kuadran tertentu dalam kuadran strategi SWOT. Berapapun faktor internal eksternal yang dipertimbangkan, total nilai tertimbang yang dihasilkan akan berkisar dari 1,0 untuk sangat rendah sampai dengan 4,0 untuk yang sangat tinggi, dengan skor rataannya 2,5 . Dengan demikian, jika dari matriks EFI dan EFE ditemukan bahwa hasil yang diperoleh dibawah 2,5, berarti keadaan yang ada belum mampu memanfaatkan kekuatan atau peluang secara optimal dan sangat rentan terhadap kelemahan dan ancaman. Dengan kata lain, dalam menghadapi dinamika lingkungan internal ekternal, sedang dalam posisi lemah. Sebaliknya, jika hasilnya lebih besar dari 2,5, dapat disimpulkan bahwa dalam menghadapi dinamika lingkungan eksternal posisinya relatif kuat,

3. Tahap pengambilan keputusan (penentuan alternatif strategi). Dalam tahap ini dilakukan dengan merujuk kembali terhadap faktor yang memiliki bobot yang paling berpengaruh terhadap pencapaian tujuan. Strategi pada matriks hasil SWOT dihasilkan dari penggunaan unsur-unsur kekuatan untuk mendapatkan peluang (SO), penggunaan peluang yang ada untuk menghadapi ancaman (ST), penggunaan kelemahan dengan memanfaatkan peluang yang ada (WO) dan penggunaan kelemahan untuk menghadapi ancaman yang akan datang (WT). Strategi yang dihasilkan terdiri dari berbagai alternatif (tema-tema) strategi yang dibuat berdasarkan posisi kuadran SWOT.

\section{HASIL DAN PEMBAHASAN}

\subsection{Evaluasi faktor internal konsep pengembangan industri pengolah- an ikan}

1. Lokasi, fasilitas dan Aksesibilitas Pengembangan industri di Kota Palopo skala sedang hingga besar di pusatkan di Kawasan Industri Palopo (KIPA). Kawasan ini ditujukan untuk industri ringan/menengah, yang mana pendirian industri ini dimaksudkan sebagai industri pendukung produksi pertanian, perikanan, hutan, perkebunan dan peternakan Kawasan Andalan Palopo dan sekitarnya. Hasil tangkapan ikan Kota Palopo bersumber pada satu kawasan yakni di Pangkalan Pendaratan Ikan (PPI) Pontap. PPI Pontap merupakan kawasan yang menjadi pusat kegiatan perikanan tangkap di Kota Palopo. KIPA berada di Kecamatan Telluwanua, yang merupakan bagian utara Kota Palopo, meskipun infrastruktur jalan menuju lokasi KIPA sangat baik (beraspal), melihat jarak Kawasan Industri Palopo dengan PPI 
Pontap yang cukup jauh, maka dapat dikatakan bahwa lokasi industri ini kurang sesuai untuk kegiatan industri pengolahan ikan. Industri pengolahan ikan menuntut bahan baku (ikan) yang segar, oleh sebab itu lokasi pendirian industrinya harus dekat dengan sumber bahan baku (ikan). Pendirian industri pengolahan ikan sangat baik jika didirikan di dalam area PPI Pontap mengingat jarak antara tempat pendaratan ikan dengan tempat pengolahan jadi lebih dekat. Menurut Lubis (2011), pelabuhan perikanan sangat berperan terhadap pengembangan industri perikanan. Keuntungan dari industri perikanan yang berlokasi di pelabuhan akan menghemat biaya transportasi darat khususnya apabila bahan bakunya sebagian besar dari pelabuhan tersebut. Wilayahnya PPI Pontap sangat strategis, yakni dekat dengan pusat pelayanan kota (PPK)/ pusat kota sehingga mempermudah pemasaran ikan untuk konsumsi lokal dan berada di tengah-tengah perbatasan wilayah Luwu dan Luwu Utara sehingga mempermudah pemasaran ikan ke luar Kota Palopo.

Pengembangan fasilitas kegiatan perikanan tangkap hingga saat ini masih terpusat di PPI Pontap. Terdapat satu unit gedung pengolahan yang telah dibangun namun tidak beroperasi sebagaimana mestinya. Gedung pengolahan yang awalnya ditujukan untuk industri ikan kaleng, saat ini telah berubah fungsi menjadi gudang rumput laut. Hal ini dikarenakan tidak adanya investor yang berinvestasi. Kegiatan/usaha nelayan dalam memasarkan hasil tangkapannya ditunjang dengan tersedianya Pangkalan Pendaratan Ikan (PPI) dengan fasilitasnya sebagai berikut: jaringan listrik, jalan keluar, jalan masuk, pos jaga, tempat penyimpanan ikan (cilling room), gedung pengolahan, gudang rumput laut, gedung Unit Pembuat Pakan Ikan, balai pertemuan nelayan (workshop), mushollah, kios penjualan hasil pengolahan perikanan, pabrik es (balok dan curah), Stasiun pengisian bahan bakar nelayan (SPBN), docking kapal, tambat labuh, dan tempat perbaikan jaring.

Tenaga listrik dan air merupakan variabel yang penting untuk diperhatikan dalam pemilihan lokasi industri. Di Kota Palopo terdapat pembangkit listrik tenaga diesel (PLTD) dengan kapasitas $12 \mathrm{MW}$ dan pembangkit listrik tenaga mikrohidro
(PLTMH) yang berlokasi di Bambalu Kecamatan Wara Barat. Pembangkit listrik tenaga mikrohidro merupakan sistem jaringan interkoneksi jaringan regional Sulawesi saluran transmisi tegangan menengah $150 \mathrm{KV}$ dan rencana saluran transmisi tegangan tinggi (SUTT). Kota Palopo juga telah melakukan peramalan akan tingkat pelayanan jaringan listrik di wilayah Kota Palopo hingga tahun 2031 (Dinas Tata Ruang dan Cipta Karya Kota Palopo 2011). Saat ini terdapat beberapa lokasi instalasi pengolah air (IPA) di Kota Palopo yang tersebar di 3 kelurahan di Kota Palopo, yaitu:

1. IPA Saringan Pasir Lambat (SPL) di Kelurahan Latuppa dengan kapasitas produksi $40 \mathrm{~L} /$ detik.

2. IPA 1 di Kelurahan Latuppa dengan kapasitas produksi 40 1/detik.

3. IPA 2 di Kelurahan Latuppa dengan kapasitas produksi 100 1/detik.

4. IPA 3 di Kelurahan Latuppa dengan kapasitas produksi 70 1/detik.

5. IPA 4 di Kelurahan Magandang dengan kapasitas produksi 50 1/detik.

6. IPA 5 di Kelurahan Latuppa dengan kapasitas produksi 50 1/detik.

7. IPA 6 di Kelurahan Latuppa dengan kapasitas produksi 20 1/detik.

8. IPA Bronceptering di Kelurahan Buludatu dengan kapasitas produksi 2.5 $1 /$ detik.

Kondisi air tanah sebagai baku air bersih di Kota Palopo saat ini masih relatif baik. Cadangan air tanah paling banyak di Kecamatan Battang, Mungkajang dan Telluwanua. Lebih jelasnya mengenai sumber air baku beserta kapasitasnya dapat dilihat pada Tabel 1 .

Posisi Kota Palopo sangat strategis karena merupakan daerah perbatasan. Pemerintah daerah provinsi Sulawesi Selatan telah menetapkan Kota Palopo sebagai Pusat Kegiatan Wilayah (PKW) dan Pusat pengembangan ekonomi Sulawesi Selatan bagian utara (Kawasan Andalan Palopo dan sekitarnya). Hal ini membuat pemerintah daerah lebih memperkuat aksesibilitas menuju dan keluar Kota Palopo. Hal ini terlihat dari rencana pemerintah daerah yang meningkatkan fungsi Pelabuhan Tanjung Ringgit, pembangunan jalur kereta api bagian timur Sulawesi Selatan, dan terminal penumpang. Rencana pengembangan terminal penumpang di Kota Palopo meliputi terminal penumpang Regional Tipe A, Terminal Tipe B dan Terminal Tipe C, serta 
Terminal Barang. Tingginya tingkat aksesibilitas juga diperlihatkan dengan dekatnya jarak Bandara Udara Bua yang terdapat di Kabupaten Luwu yang berbatasan dengan sebelah selatan Kota Palopo.

Jaringan transportasi mempunyai peranan yang sangat penting dalam pengembangan suatu wilayah, yaitu memberi kemudahan atau meningkatkan interaksi antar wilayah/pusat pelayanan. Dengan demikian akan diperoleh manfaat ekonomi, sosial, dan kewilayahan (membuka keterisolasian dengan wilayah lainnya), karena hubungan antar wilayah yang semakin mudah akan mendorong pergerakan penduduk. Dengan terbukanya wilayah yang terisolasi maka wilayah tersebut akan semakin berkembang, yang pada akhirnya akan meningkatkan perkembangan dan pertumbuhan ekonomi. Rencana penguatan aksesibilitas menjadi peluang dalam pengembangan kegiatan industrialisasi, termasuk di dalamnya industri pengolahan ikan.

2. Jumlah dan Sumber Produksi Hasil

Tangkapan Ikan

Produksi hasil tangkapan ikan di Kota Palopo berpusat pada satu pangkalan pendaratan ikan (PPI) yakni di PPI Pontap. Sejak tahun 2003 hingga tahun 2008 volume produksi ikan yang didaratkan di PPI Pontap cenderung stabil
1.000-2.000 ton ikan per tahun. Baru pada tahun 2009, 2010, 2011 dan 2012 volume produksi ikan yang didaratkan meningkat hingga masing-masing mencapai 7.010,27 ton; 9.442,00 ton; $9.473,75$ ton dan $11.310,10$ ton. Secara keseluruhan, trend produksi ikan mengalami peningkatan setiap tahunnya. Peningkatan volume produksi juga secara langsung meningkatkan nilai produksi ikan. Volume dan nilai produksi hasil perikanan se-Kota Palopo dalam kurun waktu sepuluh tahun terakhir disajikan pada Tabel 2.

Hasil estimasi daya serap pasar lokal terhadap ikan segar di Kota Palopo tahun 2012 adalah sebesar 6.552,49 ton ikan per tahun. Produksi perikanan tangkap Kota Palopo tahun 2012 diketahui sebesar $11.310,10$ ton ikan per tahun, jadi sisa ikan yang dapat diolah (bahan baku) adalah sebesar 4757.61 ton ikan per tahun.

Berbagai studi literatur dilakukan dan disimpulkan bahwa kapasitas produksi atau jumlah bahan baku (ikan) untuk skala industri rumah tangga adalah 5-10 kilogram per hari, indutri skala kecil dengan kapasitas 25 kilogram per hari, industri sedang berkapasitas 1 kuintal per hari, dan industri besar berkapasitas 10 ton per hari.

Tabel 1. Intake/Sumber Air Baku Kota Palopo dan Kapasitasya

\begin{tabular}{c|l|l|c|c}
\hline No & \multicolumn{1}{|c|}{ Sumber Air Baku } & \multicolumn{1}{|c|}{ Lokasi Sumber } & $\begin{array}{c}\text { Jenis } \\
\text { Sumber }\end{array}$ & Kapasitas \\
\hline 1 & Sungai Mangkaluku & Sungai Mangkaluku & Sungai & $1201 /$ detik \\
2 & Sungai Latuppa & Sungai Latuppa & Sungai & $4001 /$ detik \\
3 & Sungai Magandang & Sungai Magandang & Sungai & $201 /$ detik \\
4 & Sungai Buludatu & Sungai Buludatu & Sungai & $51 /$ detik \\
5 & Sungai Bambalu & Sungai Bambalu & Sungai & $4001 /$ detik \\
6 & Sungai Babak & Sungai Babak & Sungai & $1001 /$ detik \\
\hline \multicolumn{2}{rl}{ Sumber: PDAM Kota Palopo, 2011 }
\end{tabular}

Tabel 2. Produksi dan nilai produksi hasil perikanan se-Kota Palopo tahun 2003-2012

\begin{tabular}{c|r|r}
\hline Tahun & Jumlah Produksi (ton) & Nilai Produksi (Rp.000) \\
\hline 2003 & $1.835,80$ & 9.379 .610 \\
2004 & $2.104,87$ & 12.731 .500 \\
2005 & $1.041,34$ & 6.048 .998 \\
2006 & $1.429,83$ & 7.844 .065 \\
2007 & $1.429,83$ & 11.826 .471 \\
2008 & $1.638,44$ & 15.982 .843 \\
2009 & $7.010,27$ & 91.355 .405 \\
2010 & $9.442,00$ & 145254997 \\
2011 & $9.473,75$ & 145.958 .740 \\
2012 & $11.310,10$ & 156.524 .100 \\
\hline \multicolumn{2}{|c|}{ Sumber: Dinas kelautan dan perikanan Kota Palopo (data diolah) }
\end{tabular}


Mempertimbangkan estimasi daya serap pasar lokal untuk ikan segar Kota Palopo, serta jumlah ikan yang tersisa untuk diolah maka disimpulkan bahwa skala industri yang dapat berkembang di Kota Palopo adalah skala industri rumah tangga, kecil, dan sedang. Produksi hasil tangkapan yang didaratkan di PPI Pontap didominasi oleh ikan-ikan pelagis, sebagian ikan-ikan demersal dan umumnya bernilai ekonomis penting. Hasil tangkapan yang dominan didaratkan di PPI Pontap diantaranya: kembung, layang, banjar, tembang, teri, cakalang, tongkol, kakap dan kerapu.

Sebagai salah satu pusat tempat pendaratan ikan di Sulawesi Selatan, hasil tangkapan yang di daratkan di Pangkalan Pendaratan Ikan (PPI) Pontap tidak hanya berasal dari tangkapan nelayan lokal tetapi juga datang dari beberapa daerah lain, yaitu Bulukumba, Makassar, Pare-pare, Bone, Sinjai, Palu, Bungku, Ponrang, dan Kendari. Keberadaan penyuplai ikan ini dapat menjadi indikator positif untuk pengembangan industri pengolahan ikan. Hal ini juga terjadi di Pelabuhan Perikanan Pantai (PPP) Muncar ketika produksi lebih sedikit dari yang dibutuhkan yakni mendatangkan ikan untuk bahan baku industri dari luar daerah yaitu Grajagan, Tuban dan Puger (Lubis et al, 2013). Demikian juga yang terjadi di PPN Palabuhanratu yang mendatangkan bahan baku dari daerah lain yaitu Ujung Genteng dan Cisolok terutama apabila produksi pelabuhan menurun (Lubis \& Sumiati, 2011). Oleh karena industri pengolahan ikan belum berkembang di Kota Palopo, maka hingga saat ini jika hasil tangkapan nelayan di Kota Palopo melimpah, selain dikeringkan dan atau diasinkan, ikan segar akan segera dipasarkan ke Makassar, Pare-pare, Masamba, Toraja, Enrekang, Sengkang, Soroako, Soppeng, dan Pinrang.

3. Sumberdaya manusia

Jumlah pencari kerja yang belum ditempatkan di Kota Palopo berdasarkan keahlian utama sebesar 4.181 orang (Tabel 3). Pengadaan industri sangat besar manfaatnya dalam penyerapan tenaga kerja. Besarnya jumlah pencari kerja menurut keahlian utama tenaga produksi, operator dan buruh kasar mengindikasikan masih terbukanya peluang terpenuhinya kebutuhan tenaga kerja untuk industri skala rumah tangga, kecil dan sedang. Kebutuhan tenaga profesional dan teknisi juga dapat terpenuhi dengan melihat banyaknya jumlah tenaga profesional dan teknisi, saat ini tidak dijelaskan menurut bidangnya. Tenaga kepemimpinan dan ketatalaksaaan juga telah tersedia. Selain itu, berdasarkan Tabel 4 juga diketahui bahwa kualitas SDM Kota Palopo cukup baik jika ditinjau dari segi tingkat pendidikannya. Jadi secara keseluruhan kebutuhan akan tenaga kerja atau SDM yang tepat dan mumpuni telah tersedia di Kota Palopo, namun mendatangkan tenaga kerja dari luar Kota Palopo masih tetap bisa dilakukan khususnya untuk tenaga profesional dan teknisi jika diketahui bahwa tidak ada tenaga profesional dan teknisi di bidang pengolahan ikan. Menurut Syahruddin (2010), pengembangan kawasan industri akan meningkatkan pertumbuhan ekonomi suatu wilayah. Melalui pertumbuhan ekonomi satu persen saja dapat menyerap tenaga kerja sekitar seratus ribu orang (Soeling, 2007).

Tabel 3. Jumlah Pencari Kerja yang belum Ditempatkan menurut Keahlian Utama di Kota Palopo Tahun 2012

\begin{tabular}{l|l|l|l}
\hline No. & \multicolumn{1}{|c|}{ Keahlian Utama } & \multicolumn{1}{|c}{ Jumlah } & \multicolumn{1}{|c}{ Persentase } \\
\hline 1 & Tenaga Profesional, Teknisi & 1095 & 26.19 \\
2 & Tenaga Kepemimpinan dan Ketatalaksanaan & 217 & 5.19 \\
3 & Tenaga Tata Usaha dan Tenaga yang & 2631 & 62.93 \\
& berhubungan & 27 & \\
4 & Tenaga Usaha Penjualan & 31 & 0.65 \\
5 & Tenaga Usaha Jasa & 70 & 1.67 \\
6 & Tenaga Usaha Pertanian, Peternakan, & & \\
& Kehutanan, Perkebunan dan Perikanan & 110 & 2.63 \\
7 & Tenaga Produksi, Operator dan Buruh Kasar & 4181 & 100 \\
\hline
\end{tabular}

Sumber : Dinas Sosial Tenaga Kerja dan Transmigrasi Kota Palopo (2013) 
Tabel 4. Jumlah pencari kerja yang belum ditempatkan menurut tingkat pendidikan di Kota Palopo tahun 2012

\begin{tabular}{l|c|c|c|c}
\hline \multicolumn{1}{c|}{ Tingkat Pendidikan } & $\begin{array}{c}\text { Laki-laki } \\
\text { (orang) }\end{array}$ & $\begin{array}{c}\text { Perempuan } \\
\text { (orang) }\end{array}$ & $\begin{array}{c}\text { Jumlah } \\
\text { (orang) }\end{array}$ & $\begin{array}{c}\text { Persentase } \\
\text { (\%) }\end{array}$ \\
\hline Tamat SD dan Sederajat & 4 & - & 4 & 0,10 \\
SLTP Umum & 8 & 4 & 12 & 0,29 \\
SLTA Umum & 1.070 & 1.254 & 2.332 & 55,78 \\
SLTA Kejuruan,D1/D2 & 286 & 223 & 509 & 12,17 \\
Sarjana Muda/D3/Akte 3 & 106 & 361 & 467 & 11,17 \\
Sarjana & 393 & 464 & 857 & 20,50 \\
JUMLAH & 1.875 & 2.306 & 4.181 & 100,00 \\
Tahun 2011 & 1.698 & 2.012 & 3.710 & 100,00 \\
& & & & \\
\hline
\end{tabular}

Sumber : Dinas Sosial Tenaga Kerja dan Transmigrasi Kota Palopo (2013)

\subsection{Evaluasi faktor eksternal konsep pengembangan industri pengolah. an ikan}

1. Arah kebijakan pemerintah daerah Kota Palopo

Kebijakan penetapan struktur ruang wilayah Kota Palopo meliputi (Dinas Tata Ruang dan Cipta Karya Kota Palopo 2011): (1) Perwujudan pusat kegiatan yang memperkuat kegiatan agroindustri, perdagangan dan jasa serta pariwisata dan kegiatan kota lainnya secara optimal. (2) Peningkatan aksesibilitas dan transportasi yang dapat mengarahkan peningkatan fungsi dan keterkaitan antar pusat kegiatan dan sistem sirkulasi kota yang optimal. (3) Peningkatan kualitas dan jangkauan pelayanan sarana dan prasarana yang dapat mendorong perkembangan kegiatan dan perbaikan lingkungan permukiman kota. Dinas Kelautan dan Perikanan Kota Palopo juga memberikan dukungannya yang terlihat dari arah kebijakannya. Pemanfaatan sumberdaya kelautan dan perikanan Kota Palopo ke depan akan dikembangkan melalui berbagai industri kelautan dan perikanan yang berorientasi pasar dan berbasis pada kelestarian lingkungan. Program kerja bidang pemasaran DKP Kota Palopo yaitu (1) pengembangan sarana dan prasarana pengolahan dan pemasaran produksi perikanan; serta (2) promosi atas hasil produksi perikanaan unggulan daerah.

Kebijakan pemerintah daerah memperlihatkan adanya dukungan pemerintah Kota Palopo dalam upaya pengembangan industri di Kota Palopo. Hal ini merupakan langkah awal yang baik atau peluang yang dimiliki Kota Palopo untuk menuju kota industri. Sebuah teori pemilihan lokasi industri secara komprehensif menyatakan bahwa belakangan ini faktor stabilitas politik merupakan faktor yang penting bagi pertimbangan para investor. Hal ini berkaitan dengan kelangsungan usaha jangka panjang daripada sekedar laba yang besar tetapi tidak terdapat kepastian berusaha dalam jangka panjang (Tarigan, 2009). Langkah yang telah dilakukan oleh pemerintah daerah untuk mengembangkan kegiatan industri adalah dengan membuka Kawasan Industri Palopo (KIPA) untuk industri skala sedang hingga besar, dan menyebar lokasi pengembangan industri skala kecil di seluruh kecamatan di Kota Palopo. Mempertimbangkan tentang adanya kemungkinan pencemaran lingkungan, membuat pemerintah Kota Palopo lebih mendukung pengembangan agroindustri.

Kota Palopo memiliki dua subsektor unggulan yakni subsektor perikanan dan perkebunan. Subsektor perikanan dan subsektor perkebunan masih tetap mendominasi dalam pembentukan nilai tambah sektor pertanian. Berdasarkan laporan PDRB Kota Palopo tahun 2011, kontribusi subsektor perikanan terhadap sektor pertanian mencapai $58,22 \%$ atau $10 \%$ bagi pembentukan PDRB Kota Palopo. Kontribusi subsektor perkebunan terhadap pembentukan nilai tambah sektor pertanian hanya $28,58 \%$ atau $5,15 \%$ bagi pembentukan PDRB Kota Palopo. Sisanya yakni untuk subsektor tanaman bahan makanan, peternakan, dan kehutanan yang memberikan kontribusi sebesar $13,20 \%$ terhadap sektor pertanian atau sekitar 2,59\% bagi pembentukan PDRB Kota Palopo (BPS Kota Palopo, 2012). 


\section{Pasar}

Rata-rata tingkat konsumsi ikan perkapita nasional tahun 2012 di Indonesia mencapai $33,89 \mathrm{~kg}$ per kapita, sedangkan rata-rata tingkat konsumsi ikan perkapita Provinsi Sulawesi Selatan mencapai 42,91 kg per kapita (Ditjen P2HP, 2013). Sejak tahun 2001 sampai 2012, setiap tahun penduduk Kota Palopo meningkat, dengan laju pertumbuhan 2.72 persen (BPS Kota Palopo, 2013). Pertumbuhan ekonomi Kota Palopo juga mengalami peningkatan. Diketahui bahwa sejak tahun 2005 hingga 2011 Pendapatan Domestik Regional Bruto (PDRB) atas dasar harga konstan Kota Palopo meningkat dengan laju pertumbuhan 4.5 persen. Menurut Tambunan (2003), besarnya pasar dalam negeri yang ditentukan oleh kombinasi antara jumlah populasi dan tingkat pendapatan nasional rill perkapita (asumsi faktor lain mendukung). Masyarakat Sulawesi Selatan secara umum dan khususnya masyarakat Kota Palopo lebih menyukai mengkonsumsi ikan segar dibandingkan produk olahan. Pesatnya pertumbuhan penduduk dan urbanisasi serta kemajuan pembangunan di tiap-tiap daerah di Sulawesi Selatan dan beragamnya jenis produk olahan ikan ya-ng menggugah selera, tidak menutup kemungkinan mereka untuk mengkonsumsi produk olahan. Kota Palopo yang berada pada posisi yang strategis yakni sebagai daerah perbatasan, dapat mempermudah alur distribusi produk keluar kota. Semakin gencarnya penyuluhan "gemar makan ikan" oleh Kementrian Kelautan dan Perikanan dan beberapa instansi membuat kesadaran akan pentingnya mengkonsumsi ikan semakin meningkat. Keberadaan toko-toko swalayan juga semakin menambah peluang pemasaran produk perikanan. Pada level internasional/global, tingkat konsumsi ikan dunia semakin me-ningkatt. Berdasarkan data, $71 \%$ produk perikanan dunia yang diekspor berbentuk produk konsumsi untuk manusia. Pada tahun 2011, penduduk dunia mengkonsumsi 130,8 juta ton produk perikanan untuk kebutuhan pangan. Sekitar 23,2 juta ton lainnya digunakan untuk kebutuhan non pangan (Ditjen P2HP, 2013). Berbagai peluang di atas memungkinkan meluasnya pasar dari produk perikanan.

\subsection{Pembuatan Matriks EFI, EFE dan SWOT}

Setelah melakukan analisis lingkungan di atas, maka dapat disimpulkan faktor eksternal dan faktor internal yang mempengaruhi keberhasilan pendirian industri pengolahan hasil perikanan di Kota Palopo. Selanjutnya pembuatan matriks evaluasi faktor internal eksternal dan matriks SWOT (Gambar 1). Matriks EFI memperlihatkan total skor yang diperoleh sebesar 2,68 (Tabel 6) dan matriks EFE sebesar 2,98 (Tabel 5) yang menyimpulkan bahwa konsep ini memiliki respon yang baik terhadap berbagai kondisi lingkungannya yang ada saat ini karena nilainya berada di atas rataan yaitu 2.5 .

Hasil analisis EFI menunjukkan faktor kekuatan (Strengths) memiliki nilai lebih besar yaitu 2,00 dibanding dengan nilai faktor kelemahan (Weakness) yang bernilai 0,68. Hal ini dapat diartikan bahwa kekuatan yang dimiliki dapat memaksimalkan faktor kekuatan untuk meminimalkan faktor-faktor kelemahannnya. Faktor pengembangan strategi berdasarkan perhitungan dari nilai skoring faktor internal ialah pengurangan antara faktor kekuatan (Strengths) dan kelemahan (Weakness) yaitu 2,00 - 0,68= 1,32 dijadikan titik koordinat pada sumbu X. Berdasarkan hasil analisis EFE menunjukkan faktor peluang (Opportunities) memiliki nilai lebih besar yaitu 2,46, dibanding dengan nilai faktor ancaman (Threaths) yang bernilai 0,52. Hal ini dapat diartikan bahwa peluang yang dimiliki dapat memanfaatkan faktor peluang yang ada untuk mengatasi faktor ancaman. Faktor pengembangan strategi berdasarkan perhitungan dari nilai rating faktor eksternal ialah pengurangan antara faktor peluang (Opportunities) dan ancaman (Threaths) yaitu $2,46-0,53=1,93$ yang dijadikan sebagai sumbu Y. Hasil kualitatif antara faktor internal dan faktor eksternal akan diformulasikan pada diagram SWOT agar dapat diketahui letak kuadrannya. Setelah nilai tertimbang dijabarkan dalam diagram maka diketahui bahwa konsep berada pada posisi kuadran I atau strategi agresif. 


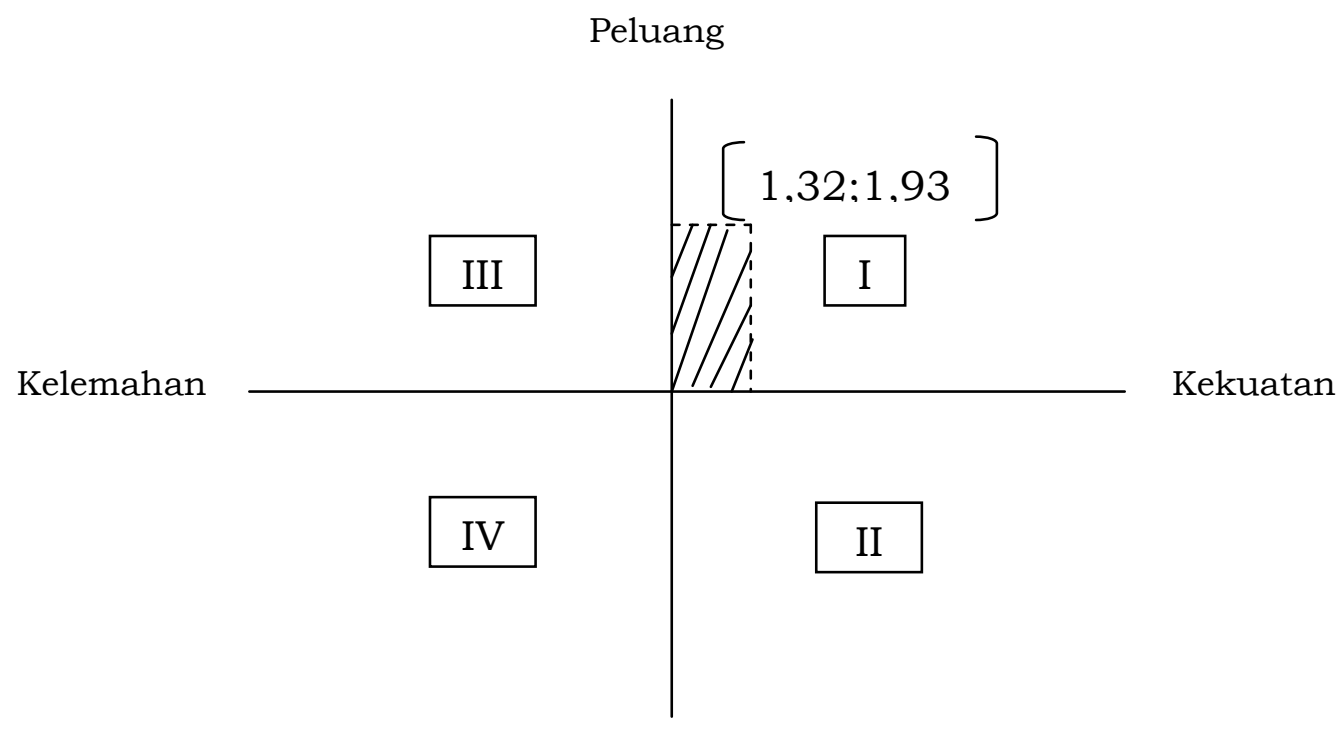

Ancaman

Gambar 1. Posisi pengembangan industri pengolahan ikan di Kota Palopo

\subsection{Pengambilan keputusan strategi}

Analisis dilanjutkan dengan pengambilan keputusan atau perumusan strategi. Beberapa alternatif strategi yang ditawarkan disajikan pada Tabel 6 . Semua alternatif strategi dapat diambil, namun oleh karena posisi konsep berada pada kuadran I atau strategi agresif maka strategi strenght-opportunity (SO) menjadi pilihan utama, yaitu:

1. Penguatan dan pengembangan kelompok pengolah ikan terpadu masyarakat pesisir.

Strategi ini dirumuskan dengan memperhatikan faktor kekuatan internal nomor 1 dan peluang eksternal nomor 2 dan 5. Langkah awal penerapan strategi ini dapat dilakukan dengan arahan atau bimbingan instansi yang kompeten di bidang pengolahan hasil perikanan. Oleh karena permasalahan utama adalah modal, maka prinsip penguatan dan pengembangan kelompok ini adalah untuk meminimalisir kebutuhan modal. Penguatan dilakukan pada manajemen kelompok pengolah ikan yang telah berdiri, sedangkan pengembangan dilakukan dengan membentuk kelompok pengolah ikan baru. Kelompok dibentuk dari anggota keluarga nelayan agar dapat sekaligus membantu perekonomian keluarga. Kelompok dapat dibentuk berdasarkan daerah tempat tinggal atau pun jenis alat tangkap. Pemukiman nelayan di Kota Palopo sebagian besar terkonsentrasi pa- da satu daerah menurut jenis alat tangkap yang dioperasikannya.

2. Memanfaatkan dan memelihara fasilitas penanganan hasil tangkapan yang tersedia seperti chilling room, pabrik es, dan gedung pengolahan ikan.

Strategi ini dirumuskan dengan memperhatikan faktor kekuatan internal nomor 1 dan 3 serta peluang nomor 1 dan 4. Penerapan strategi ini bertujuan untuk menjaga mutu hasil tangkapan yang tidak habis terjual saat musim puncak. Oleh karena itu perhatian difokuskan pada PPI Pontap sebagai tempat penanganan bahan baku (ikan). Menurut Lubis (2011), pelabuhan perikanan sebagai pusat aktivitas ekonomi perikanan tangkap di Indonesia kondisinya masih sangat terbatas. Kondisi ini menjadi penyebab sulitnya mengharapkan investor domestik dan asing untuk berinvestasi. Strategi ini sangat baik diaplikasikan guna menjadikan PPI Pontap sebagai pusat kegiatan perikanan terpadu. Seperti yang terjadi di PPN Pengambengan yang melakukan revitalisasi, penyempurnaan, pemeliharaan dan pengembangan untuk dapat menjadi pusat kegiatan perikanan terpadu (Suherman, 2011).

3. Mengembangkan jangkauan pasar terutama produk hasil olahan perikanan.

Strategi ini memperhatikan faktor kekuatan internal nomor 4 dan peluang eksternal nomor 1 sampai 4. Pemasaran 
produk olahan ikan harus dilakukan dengan penanganan yang hati-hati untuk menjaga mutu produk olahan. Pengembangan pemasaran perlu dilakukan secara terus-menerus. Walaupun demikian, pemasaran atau pendistribusian produk olahan bisa dilakukan dalam waktu lebih lama bila dibandingkan pemasaran/pendistribusian ikan segar karena mutu produk tidak akan menurun dalam jangka waktu yang singkat. Manajemen pemasaran yang baik termasuk memperkuat akses informasi pasar perlu dilakukan untuk memperluas jangkauan pasar.

4. Mempermudah akses administrasi industri perikanan pasca tangkap di daerah.

Tabel 6. Matriks SWOT kajian pengembangan industri pengolahan ikan di Kota Palopo

\begin{tabular}{|c|c|c|}
\hline Eksternal & $\begin{array}{l}\text { Kekuatan (S) } \\
\text { 1. Trend volume produksi } \\
\text { yang terus meningkat } \\
\text { 2. Lokasi pendirian industri } \\
\text { telah tersedia dan } \\
\text { letaknya strategis } \\
\text { 3. Fasilitas pendukung } \\
\text { kegiatan industri } \\
\text { pengolahan ikan tersedia } \\
\text { seperti gedung } \\
\text { pengolahan ikan, chilling } \\
\text { room, pabrik es, dan } \\
\text { gudang. } \\
\text { 4. Tingkat aksesibilitas } \\
\text { lokal tinggi } \\
\end{array}$ & $\begin{array}{l}\text { Kelemahan (W) } \\
\text { 1. Volume produksi hasil } \\
\text { tangkapan ikan } \\
\text { nelayan lokal lebih } \\
\text { sedikit dibandingkan } \\
\text { produksi yang datang } \\
\text { dari luar Kota Palopo } \\
\text { 2. Sumberdaya modal } \\
\text { kurang } \\
\text { 3. Keterampilan sumber } \\
\text { daya manusia di } \\
\text { bidang pengolahan } \\
\text { ikan masih kurang }\end{array}$ \\
\hline $\begin{array}{l}\text { Peluang (O) } \\
\text { 1. Pasar lokal dan nasional sangat } \\
\text { besar } \\
\text { 2. Dukungan pemerintah lokal } \\
\text { dengan arah kebijakan } \\
\text { pengembangan kota industri dan } \\
\text { perbaikan serta peningkatan } \\
\text { kawasan PPI Pontap dan } \\
\text { pelabuhan niaga Tanjung Ringgit } \\
\text { 3. Dukungan pemerintah nasional } \\
\text { melalui kebijakan gemar makan } \\
\text { ikan dan peningkatan modal } \\
\text { investasi untuk industri di } \\
\text { bidang perikanan } \\
\text { 4. PPI Pontap merupakan daerah } \\
\text { pendistribusian dan pemasaran } \\
\text { ikan segar yang paling sering } \\
\text { disinggahi oleh nelayan dan } \\
\text { pedagang ikan Sulawesi Selatan } \\
\text { 5. Dukungan masyarakat sekitar } \\
\text { akan pendirian industri untuk } \\
\text { meningkatkan lapangan } \\
\text { pekerjaan }\end{array}$ & \begin{tabular}{|l} 
SO \\
1. Penguatan dan \\
pengembangan kelompok \\
pengolah ikan terpadu \\
masyarakat pesisir \\
(S1,O2,O5) \\
2. Memanfaatkan dan \\
memelihara fasilitas \\
penanganan hasil \\
tangkapan yang tersedia \\
(S1, S3, O1) \\
3. Pengembangan \\
jangkauan pasar \\
terutama produk olahan \\
hasil perikanan \\
(S4,O1,O2,O3,O4) \\
4. Mempermudah akses \\
administrasi industri \\
perikanan pasca tangkap \\
di daerah \\
(S1,S2,S3,S4,O2,O3,O4, \\
O5)
\end{tabular} & \begin{tabular}{|l} 
WO \\
1. \\
Meningkatkan daya \\
saing volume produksi \\
hasil tangkapan ikan \\
nelayan lokal Kota \\
Palopo (W1,O1 sampai \\
O5) \\
2. Melakukan promosi \\
kepada investor (W2, \\
O1 sampai O5) \\
3. Meningkatkan \\
pengetahuan dan \\
keterampilan \\
masyarakat dalam \\
bidang perikanan \\
khususnya di bidang \\
pengolahan ikan (W3, \\
O1 sampai O5)
\end{tabular} \\
\hline $\begin{array}{l}\text { Ancaman (T) } \\
\text { 1. Adanya pola musim penangkapan } \\
\text { yang mempengaruhi fluktuasi } \\
\text { volume produksi ikan setiap } \\
\text { bulan } \\
\text { 2. Budaya konsumsi ikan } \\
\text { masyarakat Kota Palopo dan } \\
\text { Sulawesi Selatan adalah } \\
\text { mengkonsumsi ikan segar } \\
\text { Kemungkinan pencemaran } \\
\text { linkungan }\end{array}$ & \begin{tabular}{|l} 
ST \\
1. Menjalin kerjasama \\
dengan nelayan dan \\
pedagang di pangkalan \\
pendaratan ikan daerah \\
lain guna mendukung \\
suplai bahan baku (ikan) \\
(W1, O1 sampai O5) \\
2. melakukan kerja sama \\
dengan nelayan dan \\
masyarakat setempat (S1 \\
sampai S4, O1 sampai \\
O5)
\end{tabular} & $\begin{array}{l}\text { WT } \\
\text { 1. Melakukan pembinaan } \\
\text { kepada nelayan dan } \\
\text { masyarakat (W1 } \\
\text { sampai W3, T1 sampai } \\
\text { T3) }\end{array}$ \\
\hline
\end{tabular}


Tabel 5. Matriks Evaluasi Faktor Internal (EFI)

\begin{tabular}{|c|c|c|c|}
\hline Uraian Faktor-faktor Internal & Bobot & Rating & Skor \\
\hline \multicolumn{4}{|l|}{ Kekuatan } \\
\hline 1. Trend volume produksi terus meningkat & 0.167 & 4 & 0.67 \\
\hline $\begin{array}{l}\text { 2. Lokasi pendirian industri telah tersedia } \\
\text { dan letaknya strategis }\end{array}$ & 0.155 & 3 & 0.47 \\
\hline $\begin{array}{l}\text { 3. Fasilitas pendukung kegiatan industri } \\
\text { perikanan pascatangkap (termasuk } \\
\text { pengolahan) tersedia seperti gedung }\end{array}$ & $\begin{array}{l}0.083 \\
0.155\end{array}$ & 3 & 0.25 \\
\hline $\begin{array}{l}\text { pengolahan ikan, chilling room, pabrik es, } \\
\text { dan gudang. }\end{array}$ & 0.107 & 4 & 0.62 \\
\hline 4. Tingkat aksesibilitas lokal tinggi & 0.202 & & \\
\hline Kelemahan & & 2 & 0.21 \\
\hline $\begin{array}{l}\text { 1. Volume produksi hasil tangkapan ikan } \\
\text { nelayan lokal lebih sedikit dibandingkan } \\
\text { produksi yang datang dari luar Kota } \\
\text { Palopo }\end{array}$ & 0.131 & 1 & 0.20 \\
\hline 2. Kurangnya modal & & 2 & 0.26 \\
\hline $\begin{array}{l}\text { 3. Keterampilan sumber daya manusia di } \\
\text { bidang pengolahan ikan masih kurang }\end{array}$ & & & \\
\hline Total skor faktor kekuatan - kelemahan & 1.00 & & 2.68 \\
\hline
\end{tabular}

Tabel 6. Matriks Evaluasi Faktor Eksternal (EFE)

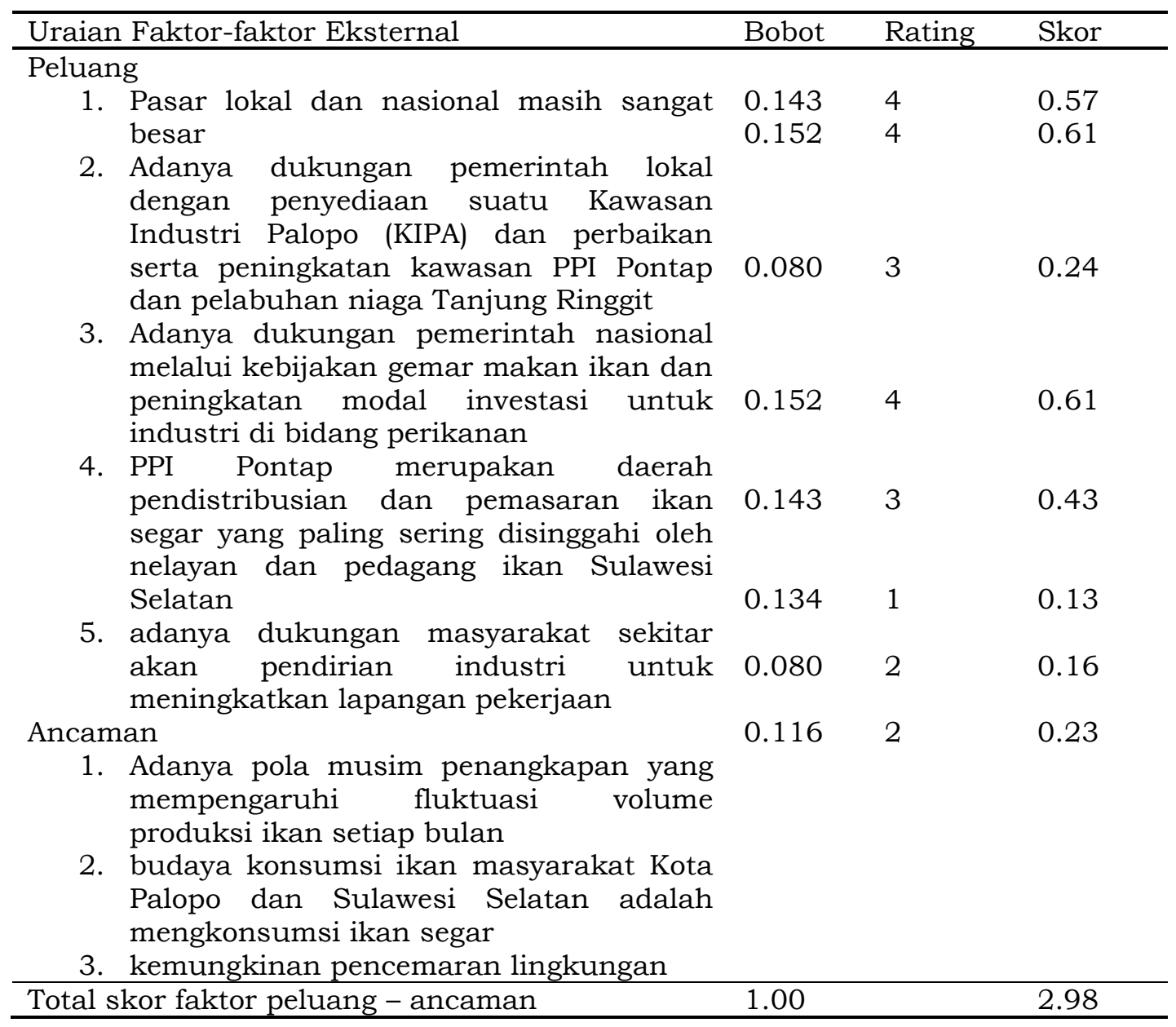


Strategi ini dirumuskan dengan memperhatikan faktor kekuatan internal untuk mengambil peluang nomor 2 sampai 5. Langkah penerapan strategi ini dengan menerapkan tata pengelolaan yang baik (good governance) guna membentuk birokrasi yang lebih profesional dan berkinerja tinggi. Diharapkan seluruh proses dalam upaya pengembangan industri yang dilakukan saling berkaitan antara kegiatan sebelumya dengan rencana selanjutnya atau antara kegiatan yang satu dengan kegiatan lainnya dalam suatu rangkaian tahapan yang saling terintegrasi. Sebagaimana yang dikemukakan oleh Edward III (1980) dalam Syahruddin (2010) bahwa suatu implementasi kebijakan akan efektif dan berdayaguna apabila perintah pelaksanaannya konsisten.Sehingga perlu adanya dukungan dari berbagai lembaga. Seperti kasus yang terjadi di PPN Untia Makassar yang perlu adanya dukungan dari berbagai lembaga dalam proses percepatan pembangunannya (Danial et al, 2011).

\section{KESIMPULAN DAN SARAN}

\subsection{Kesimpulan}

Strategi yang ditawarkan untuk pengembangan industri pengolahan ikan di Kota Palopo adalah: (1) penguatan dan pengembangan kelompok pengolah ikan terpadu masyarakat pesisir; (2) memanfaatkan dan memelihara fasilitas penanganan hasil tangkapan yang tersedia yaitu chilling room, pabrik es, dan gedung pengolahan ikan; (3) mengembangkan jangkauan pasar terutama produk hasil olahan perikanan; (4) Mempermudah akses administrasi industri pengolahan ikan di daerah; dan (5) meningkatkan daya saing volume produksi hasil tangkapan ikan nelayan lokal Kota Palopo di PPI Pontap.

\subsection{Saran}

Perlu dilakukan promosi kepada investor berkaitan dengan potensi pengembangan industri pengolahan ikan yang dimiliki Kota Palopo, melalui pengembangan unit pengolahan ikan skala kecil. Namun demikian, kajian kelayakan yang detail perlu dilakukan. Selain itu perlu memberikan pelatihan keterampilan kepada pencari kerja atau masyarakat pesisir dalam bidang pengolahan ikan agar dapat memanfaatkan sumberdaya ikan yang tersedia.

\section{DAFTAR PUSTAKA}

[BPS Kota Palopo] Badan Pusat Statistik Kota Palopo. 2012. Palopo Dalam Angka 2012.

Danial, Haluan J, Mustaruddin, Darmawan. 2011. Model Pengembangan Industri Perikanan berbasis Pelabuhan Perikanan Di Kota Makassar Sul-Sel. Jurnal Ilmiah Forum Pascasarjana IPB Bogor. 34(2): 1-11.

[DKP Kota Palopo] Dinas Kelautan dan Perikanan Kota Palopo. 2012. Laporan Tahunan Produksi Hasil Tangkapan Periode 2003-20012. Palopo (ID): DKP.

[DTRCK] Dinas Tata Ruang dan Cipta Karya Kota Palopo. 2011. Laporan Akhir Rencana Tata Ruang Wilayah Kota Palopo Tahun 2011-2031. Palopo (ID): DTRCK.

[Ditjen P2HP] Direktorat Jenderal Pengolahan dan Pemasaran Hasil Perikanan. 2013. Laporan Akuntabilitas Kinerja Direktorat Jenderal Pengolahan dan Pemasaran Hasil Perikanan. Jakarta (ID): Ditjen P2HP.

Harian Analisa. 2012. Akibat Kekurangan Es, Berton-ton Ikan Terbuang. http://www.analisadaily.com/news /kanal/9/aceh/.[29Nov 2012].

Hatta L. 2007. Degradasi Sumberdaya Pesisir dan Kelautan Sulawesi Selatan. Di dalam: Pangkajene Kepulauan, Coral Reef Rehabilitation and Management Program [Internet]. Pangkajene (ID): [diunduh 2012 Des 12]. Tersedia pada: http://www. fajar.co.id/news.php? newsid= 34480.

Kompas. 2012. Tidak Terjual, Ikan DikuburdiPasir. http://bisniskeuangan. Kompas.com/read/2012/09/12/ 1316052/Tidak.Terjual.Ikan.Dikub ur.di.Pasir. [29 Nov 2012].

Lubis E. 2011. Kajian Peran Strategis Pelabuhan Perikanan terhadap Pengembangan Perikanan Laut. Akuatik (Jurnal Sumberdaya Perairan). 5(2): 1-7. 
Lubis E, Sumiati. 2011. Pengembangan Industri Pengolahan Ikan Ditinjau dari Produksi Hasil Tangkapan di PPN Palabuhanratu. Jurnal Marine Fisheries. 2(1): 39-49.

Lubis E, Nugroho T, Witry SDB. 2013. Produksi Hasil Tangkapan Sebagai Bahan Baku Industri Pengolahan: Kasus Pelabuhan Perikanan Pantai Muncar Kabupaten Banyuwangi. Buletin PSP. 21(1): 77-95.

Mulyadi S. 2005. Ekonomi Kelautan. Jakarta (ID): PT RajaGrafindo Persada.

Najib M, Hubeis M. 2008. Manajemen Strategik dalam Pengembangan Daya Saing Organisasi. Jakarta: PT Elex Media Komputindo.

Nazdan, Setiawan B, Sukandar D. 2008. Analisis potensi dan pengelolaan perikanan dalam perspektif ketahanan pangan di wilayan perisir Kabupaten Lampung Barat. J Giz Pangan 3(3): 149-155.

Rangkuti F. 2006. Analisis SWOT Teknik Membedah Kasus Bisnis. Jakarta (ID): PT Gramedia Pustaka Utama.

Suardi. 2005. Pengembangan Perikanan Tangkap Pelagis Kecil untuk Pemberdayaan Nelayan di Kota Palopo Provinsi Sulawesi Selatan [Tesis]. Bogor (ID): Institut Pertanian Bogor.

Suherman A. 2011. Formulasi Strategi Pengembangan Pelabuhan Perikanan Nusantara Pengambengan Jembrana. Marine Fisheries Journal. 2(1): 87-99.

Soejono D. 2008. Pola Pengembangan Agroindustri Berbasis Perikanan Laut di Kecamatan Puger Kabupaten Jember. Jurnal Sosial Ekonomi Pertanian. 2(1):30-37.

Soeling PD. 2007. Pertumbuhan Bisnis dan Tanggung Jawab Sosial Perusahaan. Jurnal Ilmu Administrasi dan Organisasi, Bisnis \& Birokrasi. 15(1).

Syahruddin. 2010. Evaluasi Implementasi Kebijakan Pengembangan Kawasan Industri. Jurnal Ilmu Administrasi dan Organisasi. 17(1): 31-43.

Tambunan TTH. 2003. Perekonomian Indonesia, Beberapa Permasalahan Penting. Jakarta (ID): Ghalia Indonesia.

Tarigan R. 2009. Ekonomi Regional, Teori dan Aplikasi. PT Bumi Aksara, Jakarta. 